\title{
A Comparative Assessment of the Physico-Chemical and Microbial Trends in Njaba River, Niger Delta Basin, Southeastern Nigeria
}

\author{
Cosmas Ahamefula Ahiarakwem, Samuel O. Onyekuru \\ Department of Geosciences, Federal University of Technology Owerri, Owerri, Nigeria \\ E-mail: onyekuru2001@yahoo.com,cosahia@yahoo.com \\ Received June 19, 2011; revised July 11, 2011; accepted August 28, 2011
}

\begin{abstract}
Water quality monitoring at five (5) different gauge stations on the course of Njaba River was undertaken to understand the variability of the physico-chemical and microbial contents of the river water within a specified period of time (2003-2008). Collected water samples were analyzed using Atomic Absorption Spectrophotometer (AAS), Digital Meters and Standard Plate Counts. Results of the analyses indicated that average $\mathrm{pH}$, electrical conductivity and the Total Dissolved Solids (TDS) of the Njaba River in 2003 were 6.3, 22 $\mu \mathrm{S} / \mathrm{cm}$ and $13.5 \mathrm{mg} / \mathrm{l}$, respectively. Mean values in 2008 for the same parameters were $6.4,24.4 \mu \mathrm{S} / \mathrm{cm}$ and $14.7 \mathrm{mg} / \mathrm{l}$, respectively. Mean concentrations of analyzed cations $\left(\mathrm{Ca}^{2+}, \mathrm{Mg}^{2+}, \mathrm{Na}^{+}\right.$and $\left.\mathrm{K}^{+}\right)$in 2003 were 4.10 , $0.15,5.00$ and $1.20 \mathrm{mg} / \mathrm{l}$, respectively, and that obtained for same parameters in 2008 were 4.40, 0.18, 6.40 and $1.30 \mathrm{mg} / \mathrm{l}$, respectively. The mean concentrations of analyzed anions $\left(\mathrm{HCO}_{3}^{-}, \mathrm{SO}_{4}^{2-}, \mathrm{Cl}^{-}\right.$and $\left.\mathrm{NO}_{3}^{-}\right)$in 2003 were $20.0,4.0,1.30$ and $0.20 \mathrm{mg} / \mathrm{l}$, respectively and in 2008 the mean concentrations were $24.5,4.20$, 1.60 and $0.22 \mathrm{mg} / \mathrm{l}$, respectively. Characterization of the river water followed the trend: $\mathrm{Na}^{+}>\mathrm{Ca}^{2+}>\mathrm{K}^{+}>$ $\mathrm{Mg}^{2+}$ (for the cations) and $\mathrm{HCO}_{3}^{-}>\mathrm{SO}_{4}^{2-}>\mathrm{Cl}^{-}>\mathrm{NO}_{3}^{-}$(for anions), showing the Njaba River is $\mathrm{NaHCO}_{3}$ water. Mean concentrations of Dissolved Oxygen (DO) and Biochemical Oxygen Demand (BOD) of the river water were 7.2 and $2.2 \mathrm{mg} / 1$, respectively in 2003, and 8.0 and $4.0 \mathrm{mg} / 1$ respectively, in 2008 . Total Coliform Counts of the river water in 2003 ranged from $70-90 \mathrm{cfu} / 100 \mathrm{ml}$ with a mean value of 80 $\mathrm{cfu} / 100 \mathrm{ml}$, while the counts in 2008 ranged from $100-120 \mathrm{cfu} / 100 \mathrm{ml}$ with a mean value of $110 \mathrm{cfu} / 100 \mathrm{ml}$. Calculated Pollution Index (PI) slightly increased from 0.72 in 2003 to 0.73 in 2008 . These water quality determinants revealed gradual rise in the concentrations of the respective physico-chemical parameters and bacteriological constituents of the Njaba River water. Sodium Adsorption Ratio (SAR) of 1.37 in 2003 and 1.54 in 2008, however, indicated that the river remained excellent for irrigation purposes. Except for the observed low $\mathrm{pH}$ and poor bacteriological quality, all other measured parameters of the Njaba River water conformed to the World Health Organization (WHO) standards for safe drinking water. The generally decreasing low $\mathrm{pH}$ value and progressively increasing Coliform Counts and nutrient contents (although still low) were the major environmental problems observed in the Njaba River water. These problems are essentially associated with increased anthropogenic activities on the Njaba River Watershed within the period in focus.
\end{abstract}

Keywords: Concentration, Variability, Characterization, Water Quality, Watershed, Pollution

\section{Introduction}

Njaba River in the Niger Delta Basin is precisely located within Latitudes $5^{\circ} 44^{\prime}$ and $5^{\circ} 47^{\prime}$ North and Longitudes $6^{\circ} 49^{\prime}$ and $7^{\circ} 03^{\prime}$ East (Figures 1 and 2). The river has a shoreline length of $26.5 \mathrm{~km}$, mean depth of $4.5 \mathrm{~m}$ and an average specific discharge of about $1700 \mathrm{~m}^{3} /$ hour, [1].
The water resources master plan prepared by the Japan International Cooperation Agency (JICA) indicates an estimated surface water resource of $2.67 \times 10^{11} \mathrm{~m}^{3} /$ year and an underground storage of about $0.52 \times 10^{11} \mathrm{~m}^{3} /$ year hour, [1] in Nigeria. These figures greatly outweigh the country's total water demand of about $0.40 \times 10^{11}$ $\mathrm{m}^{3} /$ year. Although, the Njaba River is small when com- 
pared with other freshwater resources in Nigeria like rivers Niger and Benue, it is however, a very prominent river in southeastern Nigeria because of its economic and social potentials. The Njaba River is of strategic importance to both the Imo State Government of Nigeria and the local community living near its shores. Nigeria is blessed with many such abundant surface water resources, the major challenge militating against the proper utilization and sustainable development of these resources is pollution. Surface water resources are more vulnerable to pollution than ground water resources, [2], especially in developing countries where overpopulation, industrialization and improper landuse planning have generated loads of contaminants in land areas that are transported to the surface water bodies via runoff. The bacteriological quality of most of the stream waters in the area is poor, mainly due to pollution from widespread and indiscriminate human and animal defecation and very poor waste disposal practices, [3]. And the Chemical quality of surface water bodies in the study area is also impaired mainly due to industrial effluents and other anthropogenic activities, $[3,4]$.

The Njaba River, while constituting a focal point for sustainable tourism and transport development is also used for recreation, fishing, sporting, irrigation and sand mining activities. It serves as the main domestic water supply source for many people and at the same time unfortunately serves as a "pool" for sewage disposal. It is evident that human and even natural activities within and around the river have the potential to alter the physical and bio-chemical characteristics of the river and thus alter its resource status and usefulness.

A better representation of the potential problems arising from pollution sources is given by the degree of environmental damage revealed from water quality studies, [5]. And it has been remarked that unplanned development has resulted in severe environmental damage and declining quality of life for many people, [6]. Therefore, constant groundwater monitoring of a river system is required to evaluate the effects of environmental factors on water quality for proper utilization and sustainable development of the resource.

Although some studies, [3,7-10] have been carried out on surface water resources of southeastern Nigeria, there is paucity of information on the physical and bio-chemical trends of these resources that could ensure future projections on pollution loads.

One approach that is required to maintain the resource status and usefulness of the Njaba River is the development of appropriate pollution preventive and mitigation strategies. This can be achieved through a well programmed monitoring system that will involve a detailed periodic assessment of the physico-chemical and bacte- riological characteristics of the Njaba River ecosystem. This is the main focus of this study.

\subsection{Physiographic Setting and Hydrology}

The Njaba River and its watershed are located within the equatorial climate belt of Nigeria, with mean monthly temperature range of $25^{\circ} \mathrm{C}-28.5^{\circ} \mathrm{C}$, mean rainfall of about $2500 \mathrm{~mm}$; most of which falls between the months of May and October, [11].

The vegetation cover of the Njaba area is characterized by trees and shrubs of the rainforest belt of Nigeria. However, human activities such as agriculture, hydrocarbon exploration and exploitation in the area have resulted in the deforestation of part of study area.

The Njaba River originated from Amucha, Imo State, Nigeria and flows in an almost east-western direction where it empties into the Oguta Lake. Oguta Lake is the largest freshwater resource of southeastern Nigeria. The Njaba River with a mean velocity of about $0.50 \mathrm{~m} / \mathrm{s}$ contributes about $60 \%$ of the total channel inflow into Oguta Lake, [8]. The Njaba River on the other hand is adequately recharged by precipitation during the rainy season.

\subsection{Geology}

The study area is underlain by the Benin Formation (a major lithostratigraphic unit in the Niger Delta Basin, Nigeria (Figure 1). The formation which is Pliocene to Miocene in age is comprised of friable sands with intercalations of clayey-shale lenses and isolated units of gravels, conglomerates, very coarse sands and sandstones, [12].

\section{Materials and Methods}

Surface water samples were obtained at five gauge stations $\left(\mathrm{S}_{1}\right.$ to $\left.\mathrm{S}_{5}\right)$ located at equal distances of $5 \mathrm{~km}$ along the stretch of Njaba River (Figure 2). Spot sampling was monitored for two periods (2003 and 2008) on a bimonthly basis commencing from January (for each year). The data obtained in 2003 provided the baseline line for monitoring the physical and bio-chemical trends of the Njaba River.

Three 2.5-litre sample bottles that were previously prepared (treated) were used to obtain spot water samples using the grab method from the predetermined points on the course of the Njaba River. After collection, the sample bottles were immediately corked under water to prevent oxidation. Of the three samples collected, one was immediately analyzed for the following parameters in the field: $\mathrm{pH}$, Temperature, Electrical Conductivity, 


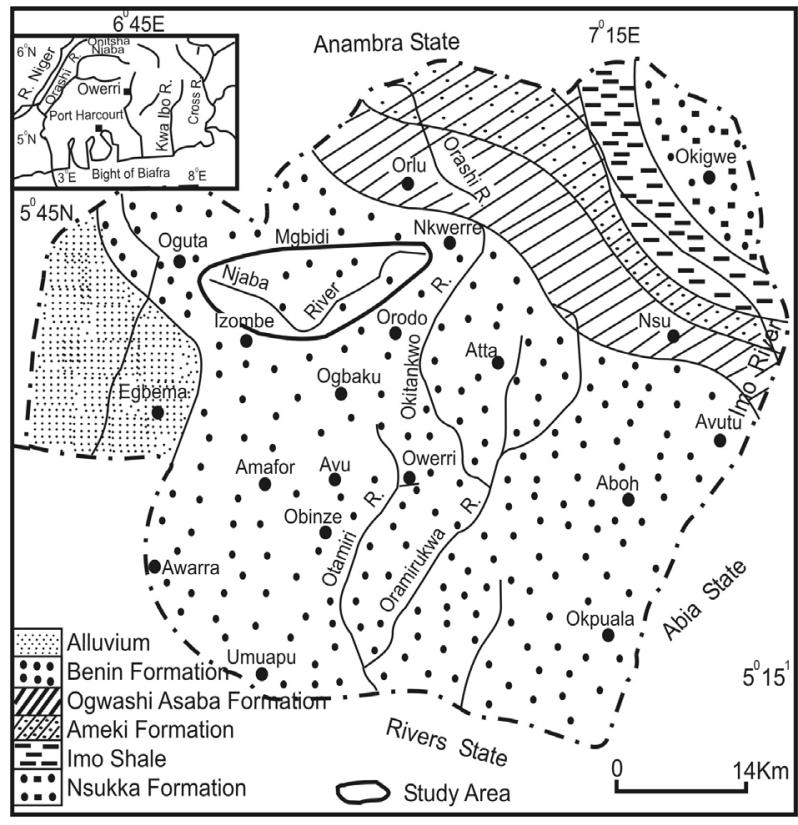

Figure 1. Geological map of Imo state showing the study area.

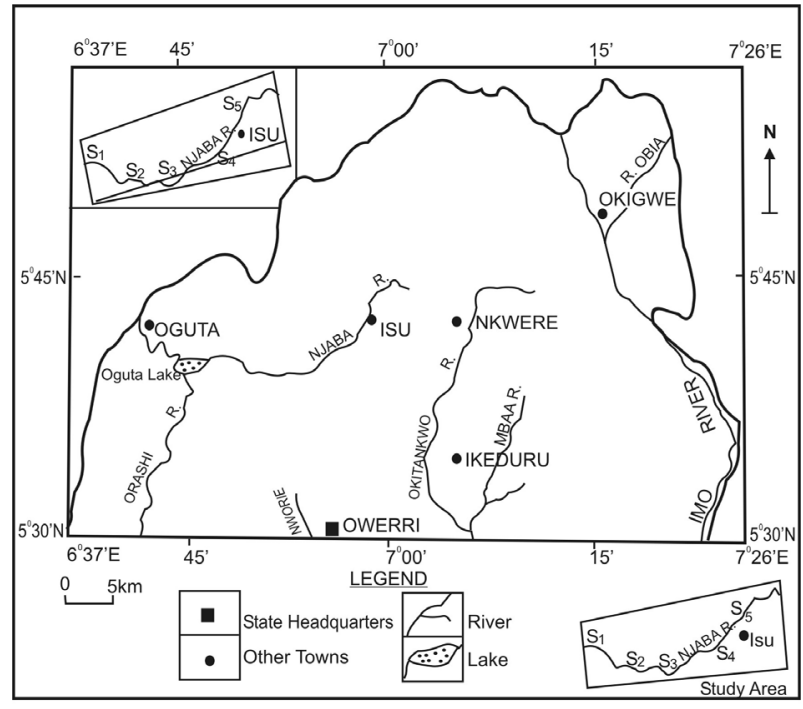

Figure 2. Sampling locations.

Total Dissolved Solids (TDS) and Dissolved Oxygen) using Digital Meters. A second sample was preserved in a cooler of ice (usually, below $5^{\circ} \mathrm{C}$ ) and later sent to the laboratory. Part of the sample was used to conduct a bacteriological analysis with Standard Plate Counts, while the other part was analyzed of major constituent cations and anions using the Atomic Absorption Spectrometer (AAS).

The third sample used for the determination of the Biochemical Oxygen Demand (BOD) was treated in quick successions in $1 \mathrm{ml}$ Potassium Fluoride solution and $2 \mathrm{ml}$ Manganese Sulphate solution and properly corked. The corked sample was later sent to the laboratory within 24 hours for analyses. The BOD was evaluated by first diluting the sample and incubating it in the dark at $20^{\circ} \mathrm{C}$ for five days and measuring the amount of oxygen consumed.

\section{Results and Data Analysis}

The results of field measurements $(\mathrm{pH}$, Total Dissolved Solids, Total Alkalinity, Electrical Conductivity and Dissolved Oxygen) and those obtained after analysis of the river samples in the laboratory are shown in Table 1.

The concentrations of the major cations and anions of the river were converted from milligram/litre to milliequivalent/litre (Table 2) using Equation (1) below, and subsequently used to construct the Stiff and Piper Trilinear Diagrams (Figures 3 and 4).

Milliequivalent $\left(\right.$ litre $\left.^{-1}\right)=$ Milligram $\left(\right.$ litre $\left.^{-1}\right) /$ Equivalent mass

The mean concentrations of $\mathrm{Na}^{+}, \mathrm{Ca}^{2+}$ and $\mathrm{Mg}^{2+}$ in milliequivalent/litre were used to determine the Sodium Adsorption Ratio (SAR) values.

The SAR was determined using Equation (2) as developed by the United States Department for Agriculture [13].

$$
\begin{aligned}
\mathrm{SAR} & =\mathrm{Na}^{+} /\left(\mathrm{Ca}^{2+}+\mathrm{Mg}^{2+}\right)^{0.5} \\
\mathrm{SAR}_{2003} & =(0.217 / 0.1085)^{0.5}=1.37 \\
\mathrm{SAR}_{2008} & =(0.278 / 0.1175)^{0.5}=1.54
\end{aligned}
$$

Mean concentrations of $\mathrm{pH}$, Total Alkalinity, Total Dissolved Solids (TDS), Total Hardness, Sulphate and Chloride in milligram/litre were used to determine the Mean Pollution Index (PI) of the river (Table 3). This was done using the method developed by, [14]

$$
\mathrm{PI}=\sqrt{(\text { Maximum } \mathrm{C} / L)^{2}+(\text { Mean } \mathrm{C} / L)^{2} / 2}
$$

where $\mathrm{C}=$ Mean Concentration of the Constituents listed above

$$
\begin{aligned}
& \mathrm{L}=\mathrm{WHO}(2006) \text { permissible levels } \\
& \mathrm{PI}_{2003}=\sqrt{(0.969)^{2}+(0.239)^{2} / 2}=0.71 \\
& \mathrm{PI}_{2008}=\sqrt{(0.984)^{2}+(0.253)^{2} / 2}=\sqrt{0.5157}=0.72
\end{aligned}
$$

The Constituent Budget (Table 4) of the river was determined using the method described by, [15]. A single conceptual model structure for a single constituent (I) is expressed as:

$$
\mathrm{Cu}-\mathrm{Co}=\Delta \mathrm{Cic} / \Delta \mathrm{t}
$$

where $\mathrm{C}_{\mathrm{u}}=$ Constituent input into the system per unit time 
Table 1. Physico-chemical and microbial analysis of $\mathrm{Njaba}$ river water.

\begin{tabular}{|c|c|c|c|c|c|}
\hline \multirow{2}{*}{ PARAMETERS } & \multicolumn{2}{|c|}{2003} & \multicolumn{2}{|c|}{2008} & \multirow[b]{2}{*}{ WHO (2006) } \\
\hline & RANGE & MEAN & RANGE & MEAN & \\
\hline $\mathrm{PH}$ & $6.2-6.6$ & 6.3 & $6.1-6.50$ & 6.40 & $6.50-9.00$ \\
\hline Electrical conductivity $(\mu \mathrm{S} / \mathrm{cm})$ & $19.0-27.0$ & 22.0 & $20-28$ & 24.40 & 1400 \\
\hline TDS, mg/l & $13.30-19.0$ & 13.50 & $15-24$ & 14.70 & 1500 \\
\hline Total hardness as $\mathrm{CaCO}_{3}, \mathrm{mg} / \mathrm{l}$ & $10-12$ & 10.6 & $10.00-12.40$ & 11.80 & $<150$ \\
\hline Total alkalinity, mg/l & $20-27$ & 21.0 & $21-32$ & 25 & \\
\hline Dissolved Silica, mg/l & $12.50-19.60$ & 18.6 & $14-22$ & 21 & \\
\hline $\mathrm{DO}, \mathrm{mg} / \mathrm{l}$ & $6.80-8.20$ & 7.2 & $6.90-8.40$ & 8.00 & \\
\hline $\mathrm{BOD}, \mathrm{mg} / \mathrm{l}$ & $1.40-3.00$ & 2.2 & $3.20-4.80$ & 4.00 & \\
\hline $\mathrm{Ca}^{2+}, \mathrm{mg} / 1$ & $4.00-4.60$ & 4.1 & $2.40-4.70$ & 4.40 & 200 \\
\hline $\mathrm{Mg}^{2+}, \mathrm{mg} / 1$ & $0.15-0.18$ & 0.15 & $0.17-0.24$ & 0.18 & 150 \\
\hline $\mathrm{Na}^{+}, \mathrm{mg} / \mathrm{l}$ & $.90-5.40$ & 5.0 & $5.50-6.60$ & 6.40 & 500 \\
\hline $\mathrm{K}^{+}, \mathrm{mg} / \mathrm{l}$ & $1.00-1.40$ & 1.2 & $1.00-1.40$ & 1.30 & 50 \\
\hline $\mathrm{HCO}_{3}^{-}, \mathrm{mg} / \mathrm{l}$ & $18.50-20.40$ & 16.6 & $18.50-25.0$ & 24.50 & 500 \\
\hline $\mathrm{SO}_{4}^{2-}, \mathrm{mg} / \mathrm{l}$ & $3.40-4.50$ & 4.0 & $3.20-4.30$ & 4.20 & 400 \\
\hline $\mathrm{NO}_{3}^{-}, \mathrm{mg} / \mathrm{l}$ & $0.18-0.22$ & 0.2 & $0.16-0.24$ & 0.22 & $40-70$ \\
\hline $\mathrm{Cl}^{-}, \mathrm{mg} / \mathrm{l}$ & $1.00-1.40$ & 1.2 & $1.20-1.80$ & 1.60 & 500 \\
\hline $\mathrm{PO}_{4}^{3-}, \mathrm{mg} / \mathrm{l}$ & $0.18-0.20$ & 0.17 & $0.17-0.23$ & 0.20 & 10 \\
\hline $\mathrm{Cu}^{2+}, \mathrm{mg} / \mathrm{l}$ & ND & & ND & & 0.05 \\
\hline $\mathrm{Pb}^{2+}, \mathrm{mg} / \mathrm{l}$ & ND & & ND & & 0.05 \\
\hline $\mathrm{Mn}^{+}, \mathrm{mg} / \mathrm{l}$ & ND & & ND & & $0.01-0.20$ \\
\hline $\mathrm{Cd}^{2+}, \mathrm{mg} / \mathrm{l}$ & ND & & ND & & 0.05 \\
\hline $\mathrm{Zn}^{2+}, \mathrm{mg} / \mathrm{l}$ & ND & & ND & & 5.00 \\
\hline Total coliform $(\mathrm{cfu} / 100 \mathrm{ml})$ & $70-90$ & 80.0 & $80-120$ & 100 & 10 \\
\hline
\end{tabular}

Table 2. Mean values of major cations and anions of Njaba river in milliequivalent/litre (Meq/I).

\begin{tabular}{|c|c|c|c|c|c|}
\hline PARAMETER & EQUIVALENT MASS & $2003 \mathrm{Meq} / \mathrm{l}$ & $2008 \mathrm{Meq} / \mathrm{l}$ & $2003 \%$, epm & $2008 \%$, epm \\
\hline $\mathrm{Ca}^{2+}$ & 20 & 0.205 & 0.220 & 44.20 & 40.20 \\
\hline $\mathrm{Mg}^{2+}$ & 12.2 & 0.012 & 0.015 & 2.60 & 2.70 \\
\hline $\mathrm{Na}^{+}$ & 23 & 0.217 & 0.278 & 46.80 & 51.00 \\
\hline \multirow[t]{2}{*}{$\mathrm{K}^{+}$} & 39.1 & 0.030 & 0.033 & 6.40 & 6.00 \\
\hline & Total & 0.464 & 0.546 & 100 & 100 \\
\hline $\mathrm{HCO}_{3}^{-}$ & 61 & 0.327 & 0.402 & 73.50 & 74.60 \\
\hline $\mathrm{SO}_{4}^{2-}$ & 48 & 0.083 & 0.088 & 18.60 & 16.30 \\
\hline $\mathrm{Cl}^{-}$ & 35.5 & 0.033 & 0.045 & 7.40 & 8.40 \\
\hline \multirow[t]{2}{*}{$\mathrm{NO}_{3}^{-}$} & 62 & 0.003 & 0.004 & 0.70 & 0.70 \\
\hline & Total & 0.446 & 0.539 & 100 & 100 \\
\hline
\end{tabular}




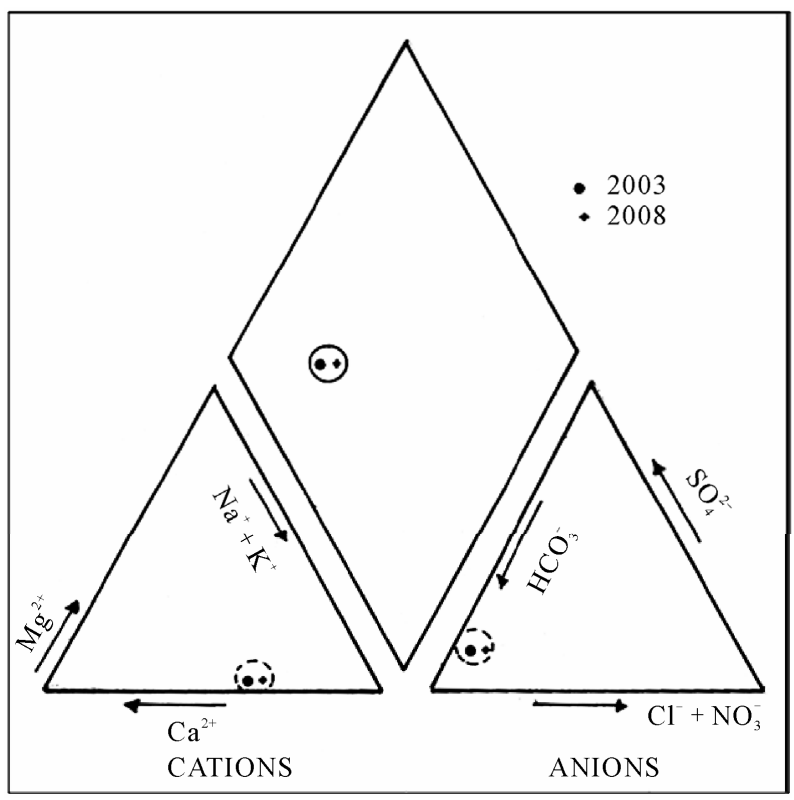

Figure 3. Piper trilinear plot of Njaba river.

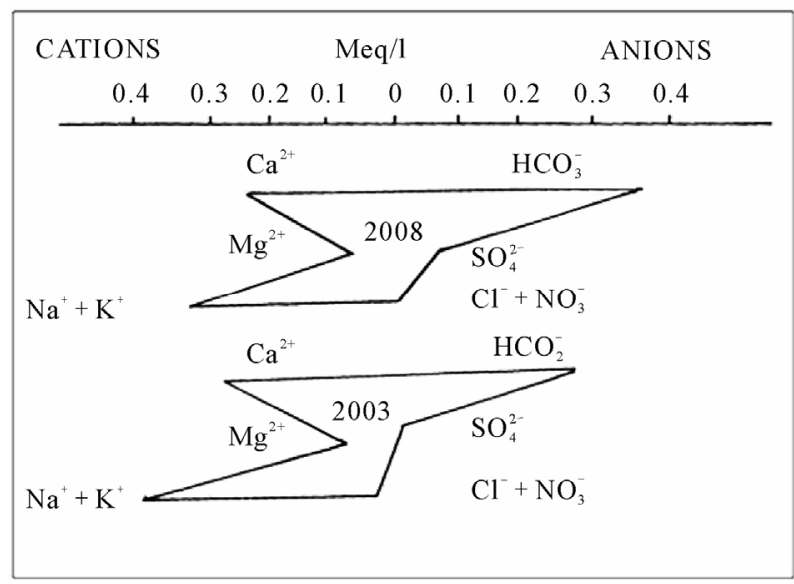

Figure 4. Stiff plot of the Njaba river water.

$\mathrm{C}_{\mathrm{o}}=$ Constituent output from the system per unit time

$\Delta \mathrm{C}_{\mathrm{ic}}=\mathrm{C}_{\mathrm{u}}-\mathrm{C}_{\mathrm{o}}$ (Change in concentrations of constituent storage within the system).
$\Delta \mathrm{t}=$ Time Interval $\left(\mathrm{t}_{2}-\mathrm{t}_{1}\right)$

In this study, equation 4 was simplified as follows:

$\mathrm{C}_{\mathrm{u}}-\mathrm{C}_{\mathrm{o}}=$ Change in mean constituent concentrations

$\left(\right.$ Conc $_{2008}-$ Conc. $\left._{2003}\right) / 5$

The change in mean constituent concentrations $\left(\mathrm{C}_{\mathrm{u}}-\right.$ $\mathrm{C}_{\mathrm{o}}$ ) is equivalent to the constituent loading rate.

\section{Discussion}

\subsection{Physical Parameters of the Njaba River Water}

The mean concentrations of $\mathrm{pH}$, Electrical Conductivity, Total Dissolved Solids (TDS), Total Alkalinity of the Njaba River water in 2003 were $6.30,22 \mu \mathrm{S} / \mathrm{cm}, 13.5$ and $21 \mathrm{mg} / \mathrm{l}$, respectively while the values in 2008 were $6.40,24.4 \mu \mathrm{S} / \mathrm{cm}, 14.70$ and $25 \mathrm{mg} / \mathrm{l}$, respectively. Except the $\mathrm{pH}$ values, other physical parameters shown in Table 1 conformed to the World Health Organization Standard for safe drinking water, [16].

It is however, noted that the reduced rate of increase in the mean concentrations of all the parameters and a lowering of the $\mathrm{pH}$ of the Njaba River Water is a potential hazard if the trend is not checked. The increased loading of pollutants, especially acid rain runoff into the Njaba River, has been attributed to incessant gas flaring activities in nearby flow stations.

\subsection{DO and BOD}

The mean concentrations of dissolved oxygen (DO) of Njaba River varies from 6.8 to $8.2 \mathrm{mg} / 1$ in 2003 with a mean value of $7.20 \mathrm{mg} / \mathrm{l}$ while the range of values in 2008 is from 6.9 to $8.4 \mathrm{mg} / \mathrm{l}$ with a mean value of 8.0 $\mathrm{mg} / \mathrm{l}$. Classification of surface water, [17] indicates that surface water with DO of 6.2 and $7.8 \mathrm{mg} / \mathrm{l}$, falls within acceptable and excellent levels, respectively. The Njaba River water is well oxygenated throughout the year. The oxygen level of the Njaba River is quite favourable for the survival of aquatic life such as fish.

Table 3. Pollution index of Njaba river.

\begin{tabular}{|c|c|c|c|c|c|}
\hline $\begin{array}{l}\text { PARAMETERS } \\
\text { CONSIDERED }\end{array}$ & $\begin{array}{l}\text { WHO LOWER } \\
\text { LIMIT (L) }\end{array}$ & $\begin{array}{c}2003 \text { MEAN } \\
\text { CONSTITUENT (C1) }\end{array}$ & $\begin{array}{c}2008 \text { MEAN } \\
\text { CONSTITUENT (C2) }\end{array}$ & $\begin{array}{c}2003 \\
(\mathrm{C} 1 / \mathrm{L})\end{array}$ & $\begin{array}{c}2008 \\
(\mathrm{C} 2 / \mathrm{L})\end{array}$ \\
\hline $\mathrm{Ph}$ & 6.50 & 6.30 & 6.40 & 0.969 & 0.984 \\
\hline $\mathrm{TDS}, \mathrm{mg} / \mathrm{l}$ & 500 & 13.50 & 14.70 & 0.027 & 0.029 \\
\hline Total alkalinity $(\mathrm{mg} / \mathrm{l})$ & 100 & 21.00 & 25.00 & 0.210 & 0.250 \\
\hline Total hardness (mg/l) & 50 & 10.60 & 11.80 & 0.212 & 0.236 \\
\hline $\mathrm{SO}_{4}^{2-}$ & 400 & 4.00 & 4.20 & 0.010 & 0.010 \\
\hline $\mathrm{Cl}^{-}$ & 250 & 1.20 & 1.60 & 0.005 & 0.006 \\
\hline
\end{tabular}


Table 4. Constituent budget of the Njaba river water.

\begin{tabular}{|c|c|c|c|c|c|c|}
\hline PARAMETERS mg/l & $2003(\mathrm{~A})$ & 2008 (B) & Time interval $(\Delta t)$ & $\mathbf{B}-\mathbf{A}\left(\Delta \mathrm{C}_{\mathrm{ic}}\right)$ & $\Delta \mathrm{C}_{\mathrm{ic}} / \Delta \mathrm{t}$ & $\%$ Increase \\
\hline Total alkalinity & 21 & 25 & 5 & 4.00 & 0.800 & 19 \\
\hline BOD & 2.20 & 4.00 & 5 & 2.80 & 0.560 & 12.70 \\
\hline sDO & 7.20 & 8.40 & 5 & 1.20 & 0.006 & 16.60 \\
\hline $\mathrm{Ca}^{2+}$ & 4.1 & 4.4 & 5 & 0.30 & 0.06 & 7.3 \\
\hline $\mathrm{Mg}^{2+}$ & 0.15 & 0.18 & 5 & 0.03 & 0.006 & 20 \\
\hline $\mathrm{Na}^{+}$ & 5.00 & 6.40 & 5 & 1.40 & 0.280 & 28 \\
\hline $\mathrm{K}^{+}$ & 1.20 & 1.60 & 5 & 0.40 & 0.080 & 33 \\
\hline $\mathrm{HCO}_{3}^{-}$ & 20 & 24.50 & 5 & 4.50 & 0.900 & 22.50 \\
\hline $\mathrm{SO}_{4}^{2-}$ & 4.00 & 4.20 & 5 & 0.20 & 0.040 & 5 \\
\hline $\mathrm{NO}_{3}^{-}$ & 0.20 & 0.22 & 5 & 0.02 & 0.004 & 10 \\
\hline $\mathrm{Cl}^{-}$ & 1.20 & 1.60 & 5 & 0.40 & 0.08 & 33 \\
\hline $\mathrm{PO}_{4}^{3-}$ & 0.17 & 0.20 & 5 & 0.03 & 0.006 & 17.60 \\
\hline Silica & 18.60 & 21 & 5 & 2.40 & 0.480 & 12.90 \\
\hline
\end{tabular}

Biochemical Oxygen Demand (BOD) of Njaba River varies from 2.2 to $3.0 \mathrm{mg} / \mathrm{l}$ in 2003 with a mean value of $2.2 \mathrm{mg} /$; the BOD ranged from 3.2 to $4.8 \mathrm{mg} / \mathrm{l}$ in 2008 with a mean value of $4.0 \mathrm{mg} / \mathrm{l}$. The BOD trend indicates a significant increase in organic input into the river within the period.

\subsection{Major Cations and Anions}

The mean concentrations of the major cations and anions of the river (Table 1) conform to World Health Organizations standard for safe drinking water, [16]. The mean values of $\mathrm{Ca}^{2+}, \mathrm{Mg}^{2+}, \mathrm{Na}^{+}$and $\mathrm{K}^{+}$of river in 2003 were $4.1,0.15,5.0$ and $1.2 \mathrm{mg} / 1$, respectively while the values in 2008 were $4.4,0.18,6.4$ and $1.3 \mathrm{mg} / \mathrm{l}$, respectively. The mean values of $\mathrm{HCO}_{3}^{-}, \mathrm{SO}_{4}^{2-}, \mathrm{Cl}^{-}, \mathrm{NO}_{3}^{-}$and $\mathrm{PO}_{4}^{3-}$ in 2003 were $20,4.0,1.2,0.20$ and $0.17 \mathrm{mg} / \mathrm{l} \mathrm{re}-$ spectively while the values obtained in 2008 were 24.5 , $4.2,1.6,0.22$ and $0.20 \mathrm{mg} / 1$ respectively. Characterization of the river water followed the trend: $\mathrm{Na}^{+}>\mathrm{Ca}^{2+}>$ $\mathrm{K}^{+}>\mathrm{Mg}^{2+}$ (for the cations) and $\mathrm{HCO}_{3}^{-}>\mathrm{SO}_{4}^{2-}>$ $\mathrm{Cl}^{-}>\mathrm{NO}_{3}^{-}$(for anions), showing the Njaba River water is $\mathrm{NaHCO}_{3}$ water.

The results indicate that the concentrations of the constituent major cations and anions of the Njaba River water is generally low (Tables $\mathbf{1}$ and 2); this is typical of most tropical African lakes, [18].

The nutrient level of the river indicated by the concentrations of nitrates and phosphates is very low; which shows that the Njaba River has very low eutrophication level, [19].

The water characteristics of the river follow the trend $\mathrm{Na}^{+}>\mathrm{Ca}^{2+}>\mathrm{K}^{+}>\mathrm{Mg}^{2+}$ for the cations and $\mathrm{HCO}_{3}^{-}>$ $\mathrm{SO}_{4}^{2-}>\mathrm{Cl}^{-}>\mathrm{NO}^{-3}$ for the anions.

\subsection{Microbial Assay}

The total coliform count of the river varies from 70 to 90 $\mathrm{cfu} / 100 \mathrm{ml}$ in 2003 with a mean value of $80 \mathrm{cfu} / 100 \mathrm{ml}$ while the values in 2008 ranged from 80 to 120 $\mathrm{cfu} / 100 \mathrm{ml}$ with a mean value of $100 \mathrm{cfu} / 100 \mathrm{ml}$. These values do not conform to the WHO standards for safe drinking water, [16]. The poor microbial assay of the river is typical of most surface water resources in the tropics. The bacteriological quality of most of the stream waters in the tropics is poor, mainly due to pollution from widespread and indiscriminate human and animal defecation and very poor waste disposal practices, [3]. This condition is a major cause of diseases such as cholera, dysentery, typhoid, among others in the area.

\subsection{Sodium Adsorption Ratio (SAR)}

The computed SAR ratio values using Equation (2) indicate that Njaba River has a mean SAR value of 1.37 and 1.54 for 2003 and 2008 respectively. According to the United States department of agriculture, [13] water with SAR value of 1 to 10 is classified as excellent for irrigation purposes while those with SAR values above 26 are considered poor. 


\subsection{Pollution index (PI)}

The mean Pollution Indices (PI) of Njaba River for 2003 and 2008 are 0.71 and 0.72 respectively. It has been noted that the critical value of Pollution Index is 1 ; hence, pollution index of more than 1 indicates very high degree of pollution, [14]. The increase in the mean PI value from 0.71 to 0.72 indicates very low rate of degradation of the river resource. However, there is need to monitor the PI value since it is already tending to the critical value of 1 .

\subsection{Constituent Budget}

The constituent budget (Table 4) indicates that total alkalinity has the highest loading rate $(0.80)$ while nitrate has the lowest loading rate $(0.004)$. The constituent budget also shows that the percentage increase (from 2003 to 2008) of chloride, sodium, potassium, magnesium and bicarbonate are 33, 28, 33, 20 and $22.5 \%$, respectively while that of BOD, alkalinity, DO, phosphate and dissolved silica are 12.7, 19, 16.6, 17.6 and 12.9\%, respectively. The percentage increase for nitrate, calcium and sulphate are 5, 6.4 and $10 \%$, respectively.

The constituent budget indicates continuous loading of constituents into the river but at a very slow rate. The percentage increase of dissolved silica $(12.9 \%)$, nitrate $(5 \%)$ and phosphate $(17.6 \%)$ indicates eutrophication of the river water (but at slow ebb).

\subsection{Water Quality}

Piper trilinear diagram (Figure 3) shows a close relationship in the chemistry of the river water in 2003 and 2008. Both plotted within the potable water zone of the diamond portion of the Piper diagram.

A further confirmation of the close relationship in the chemical characteristics of the river waters in 2003 and 2008 is shown in the Stiff diagram (Figure 4). The Stiff diagram for 2003 and 2008 has similar shape, though with slight variations in size as a result of increased concentration levels (Figure 4).

Although the Piper trilinear plot (of major cations and anions) of the river water falls within the potable zone, low $\mathrm{pH}$ and poor microbial assay has greatly impaired the quality of the Njaba River water. Proper water treatment must be done in order to make the water wholesome for human consumption.

The increasing loads organic input into the river which culminated in an increased Biochemical Oxygen Demand (BOD) calls for a more closely spaced water monitoring in order to avoid excessive levels of the constituents in the Njaba River.
Despite these limiting parameters, however, the Njaba River is suitable for agricultural (irrigation) purposes on the basis of the SAR values.

\section{Conclusions}

The physical and bio-chemical properties of the Njaba River water samples within the period (2003 to 2008) under investigation indicated an increase (at a slow rate) of contaminant loads. The trend indicated some environmental problems (low $\mathrm{pH}$, poor microbial assay and eutrophication indicating increased organic input into the river).

Necessary treatment procedures can however, be applied to raise the quality of the river water to the WHO standards for safe drinking water. For example the $\mathrm{pH}$ can be corrected (raised) using sodium bicarbonate (soda ash) while the microbial assay can be improved upon by boiling and subjection to treatment using chlorine.

The observed contamination/pollution trends in the Njaba River necessitate appropriate monitoring procedures for pollution control and mitigation for a sustainable development of the resource.

\section{Acknowledgements}

We are grateful to the Federal University of Technology, Owerri for the award of fellowship and research grants for this study. Gratitude is also due to the staff of Imo State Environmental Protection Agency (ISEPA), Nigeria for handling the analytical aspects of this research. Finally, to our beloved wives, Mrs Evangeline Ahiarakwem and Mrs Joy Onyekuru, we say thanks for your contributions.

\section{References}

[1] O. E. Oteze, "Management Approaches for Nigeria's Water Resources," Nigerian Journal of Mining and Geology, Vol. 42, No. 1, 2006, pp. 21-30.

[2] M. I. Ogubanjo and O. A. Rolajo, "The Impact of Solid Waste Disposal on the Chemical Quality of Surface and Subsurface Water Resources in parts of IBADAN Metropolis, Southwestern Nigeria," Water Resources, Vol. 15, 2004, pp. 26-32.

[3] H. I. Ezeigbo, "Groundwater Quality Problems in Parts of Imo State, Nigeria," Nigerian Journal of Mining and Geology, 25, No. 5, (1 and 2), 1989, 9 pp.

[4] K. M. Ibe, A. H. O. Sowa and O. C. Osondu, "Environmental Contamination and Other Anthropogenic Impacts on Otamiri and Nworie Rivers, Owerri Nigeria," Nigerian Journal of Mining and Geology, 28, No.1, 1992, pp. 87-91.

[5] A. Villumsen and C. Sonderskov, "Vulnerability Maps: A 
Promising Tool in Groundwater Protection," Aqua, Vol. 5, 1982, pp. 406-468.

[6] D. W. Pearce and R. K. Turner, "Economics of Natural Resources and the Environment," Harveaster Wheatsheaf, London, 1990, $378 \mathrm{pp}$

[7] C. A. Ahiarakwem, "Preliminary Bio-chemical and Hydrological Investigation of Njaba River, Imo State, Southeastern Nigeria," Unpubl. Technical Report, Federal University of Technology, Owerri, Imo State, Nigeria, 2003, $15 \mathrm{pp}$.

[8] C. A. Ahiarakwem, "Water Quality Assessment and Geochemical Models of Oguta lake, Imo State, Southeastern Nigeria," Unpubl Ph.D. Thesis, Federal University of Technology, Owerri, Imo State, Nigeria, 2007, 225 pp.

[9] R. N. Ekere, "Industrial Effluents Interaction with Ekulu River in relation to the River Recovery Characteristics," Unpubl. Ph.D. Thesis, Federal University of Technology, Owerri, Nigeria, 2004, 221 pp.

[10] G. I. Nwankwor and K. O. Okpala, "Self Potential of Small Tropical Stream: A Case Study of River Nworie in Imo State, Southeastern Nigeria," Environment Protection Engineering, Vol. 19, No. 1-4, 1993, pp. 5-17.

[11] National Root Crop Research Institute, Umudike, Abia State Climate Data, 2008.
[12] S. E. Ananaba, N. N. Onu and C. J. Iwuagwu, "Geophysical Sudy of the Gravel Deposits in Ihiagwa, Owerri, Nigeria," Nigerian Journal of Mining and Geology, Vol. 29, 1993, pp. 95-100.

[13] United States Department of Agriculture, "Classification of water for Irrigation Purposes based on Sodium Adsorption Ratio (SAR)," 1965, 20 pp.

[14] R. K. Horton, "An Index Number System for Rating Water Quality," Journal of the Water Pollution Control Federation, Vol. 37, No. 3, 1965, 12 pp.

[15] J. W. Clark, J. R. Viessman and M. J. Hammer, "Water Supply and Pollution Control," Harper and Row Publication, 1972, $856 \mathrm{pp}$.

[16] World Health Organization Standard, "Drinking Water Guidelines," Geneva, 2006, 6 pp.

[17] L. Prat, R. Pavenedo and F. Pesarin, "Assessment of Water Quality by a Single Index of Pollution," Water Research, Vol. 5, No. 9, 1970, pp. 741-751.

[18] R. N. Oliver, "Lakes of Nigeria," Nigeria Geography Stubs, 2005, 5 pp.

[19] A. B. Wilcork, "Acceptable Levels of Chemicals," Drinking Water Engineering Handbook, USA, 1993, pp. 121-140. 